\title{
Раціональне розташування за методом Монте-Карло 3D-моделей виробів у робочому просторі установки пошарової побудови
}

\begin{abstract}
Представлено результати дослідження можливостей методу Монте-Карло для виконання оптимізачійної задачі розтамування $3 D$-моделей виробів у робочому просторі почарової побудови. Запропонований спосіб розташування 3D-моделей виробів у робочому просторі 3 використанням методу Монте-Карло дає можливість зменшити час технологічної підготовки та підвищити продуктивність процесу й ефективність використання установки. Ефективність використання вдається забезпечити за рахунок зменшення відносної частки невикористаного об'єму робочого простору, щчо є актуальним для SLA, SLM, SLS та іниих методів адитивних технологій. Запропоновано покрокове визначення вільного простору для розташування наступного виробу, починаючи від платформи установки. Підвищення ефективності запропонованого алгоритму забезпечувалося шляхом формування заданої кількості варіантів розміщення з подальшим вибором найкращяго за критерієм оптимізачії. Визначено рачіональні значення параметрів алгоритму розташування на прикладі групи промислових виробів 3 достатньо складною геометрією поверхонь.

Очінка ефективності запропонованого способу розташування виконувалася на основі порівняльного аналізу кількості шарів та ефективності заповнення робочого простору (відносного об'єму його використання) для виготовлення 3D-моделей складних промислових виробів. Дослідження виконувалося з використанням спеціально розробленої підсистеми до системи «Технологічна підготовка матеріалізації складних виробів адитивними технологіями».

Ключові слова: адитивні технологї; технологічна підготовка; тріангуляиійна модель; алгоритм розташування; метод Монте-Карло.
\end{abstract}

Актуальність теми. Однією з основних задач технологічної підготовки до матеріалізації виробу адитивними методами є раціональне розташування вихідних або попередньо орієнтованих 3D-моделей у робочому просторі установки пошарової побудови [1]. Розв'язання цієї задачі досить істотно визначає ефективність використання адитивних технологій. Для низки методів пошарової побудови важливим $є$ забезпечення раціонального використання робочого простору установки. Наприклад, для SLA (лазерна стереолітографія), SLM (селективне лазерне розплавлення), SLS (селективне лазерне спікання) та інших, що належать до найбільш використовуваних у промисловості [2].

Результатом процедури розташування у робочому просторі є 3D-модель, що містить геометричний опис виробів. При цьому має задовольнятися ряд технологічних вимог. На практиці, як правило, як основні вимоги розглядають коректне розташування і раціональну орієнтацію виробів, мінімальну висоту побудови або час виготовлення, забезпечення якості одержаних поверхонь та їхніх геометричних характеристик.

Аналіз останніх досліджень і публікацій. Аналіз праць щодо розв'язання задачі раціонального розміщення 3D-моделей виробів (як правило, задачу називають щільною упаковкою, 3D-упаковкою, завантаженням або задачею про рюкзак [3-9]) засвідчує іiі істотну складність через низький рівень ефективності застосованих алгоритмів.

Алгоритм випадкового пошуку становить найбільший інтерес для розв'язання розглянутої задачі $[5,10,11]$. У таких алгоритмах відбувається генерація за рівномірним законом номера позиції або координат розміщення у робочому просторі для кожної 3D-моделі. Для отриманого випадкового розміщення підраховується значення цільової функції. Після генерації заздалегідь заданої кількості розміщень визначається краще за заданим критерієм. Переваги таких алгоритмів - це можливість проведення багатокритеріальної оптимізації. Недолік - істотне зростання витрат часу при підвищенні точності розрахунків $[7,8]$.

Відмінною особливістю цієї задачі $є$ труднощі визначення умов взаємного неперетинання 3Dмоделей виробів [7-11]. Використання воксельної моделі таку проблему усуває, але з'являється недолік це збільшення часу розрахунків.

Обчислювальна складність розв'язання цієї задачі в загальній постановці змушує вводити низку спрощень [5,8], але при цьому дозволяє знаходити оптимальні розміщення 3D-моделей 3 прийнятними витратами часу на розрахунки. Одне з найпоширеніших спрощень - фіксація орієнтації 3D-моделі в просторі або використання набору фіксованих орієнтацій кожного з них [6]. 
Основна проблема полягає в тому, що в існуючих роботах не створено методичних основ для порівняльного аналізу ефективності алгоритмів розміщення 3D-моделей з врахуванням різноманітних особливостей виробів щодо розподілу матеріалу в робочому просторі. Дослідження можливостей методу Монте-Карло для розміщення різноманітних за конструкцією виробів дозволить одержати необхідні базові показники для подальшого вивчення найбільш перспективних алгоритмів розміщення.

Метою статті $\epsilon$ обгрунтування можливості ефективного розв'язання оптимізаційної задачі раціонального розташування 3D-моделей виробів у робочому просторі пошарової побудови установок адитивних технологій з використанням методу Монте-Карло.

Викладення основного матеріалу дослідження. Реалізацію оптимізаційної задачі розміщення 3Dмоделей виробів виконано в межах системи «Технологічна підготовка матеріалізації складних виробів адитивними технологіями», розробленої на кафедрі «Інтегровані технології машинобудування» НТУ «ХПІ». Ця система дозволяє виконувати оцінку технологічності конструкції та ефективності розв'язання задач технологічної підготовки на основі статистичного аналізу досліджуваних ознак полігональної, воксельної і пошарової 3D-моделі виробів. Для розв'язання поставленої задачі розроблено підсистему раціонального розташування виробів у робочому просторі (екранна форма наведена на рисунку 1).

Розроблена підсистема надає користувачеві такі основні можливості:

- перевірка коректності розташування 3D-моделей у робочому просторі;

- створення набору шарів з 2D-перетинами на основі полігональної 3D-моделі композиції виробів (STL-файлу робочого простору) за заданою стратегією формування (з постійним або змінним кроком побудови);

- візуалізація розміщених виробів за проєкціями робочого простору;

- $\quad$ статистичний аналіз розподілу матеріалу виробів за підпросторами пошарової побудови.

Перехід від вихідної тріангуляційної 3D-моделі виробу до набору шарів виконувався за процедурою, 3 урахуванням існуючих праць $[12,13]$, що реалізує стратегії з постійним та змінним кроком побудови.

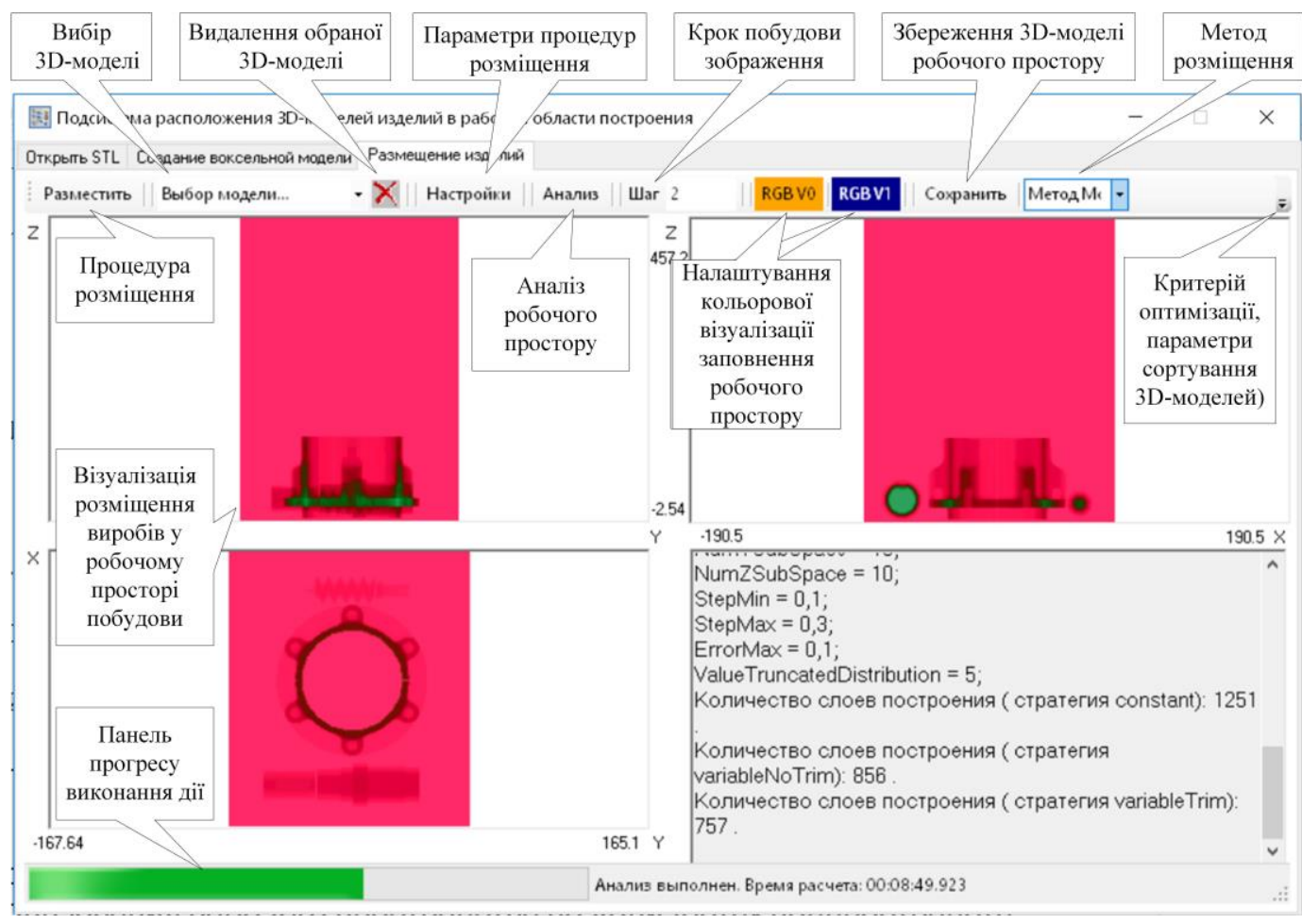

Рис. 1. Підсистема розміщення виробів у робочому просторі пошарової побудови

Передбачено такі режими формування композиції 3D-моделей виробів у робочому просторі AMустановки:

- ручний;

- $\quad$ випадковим пошуком (метод Монте-Карло);

- $\quad$ з використанням генетичного алгоритму.

Запропонована процедура розміщення з використанням методу Монте-Карло виконується за схемою, що зазначена на рисунку 2. 3 урахуванням існуючих підходів [7, 8] запропоновано виконувати розміщення 3D-моделей виробів у робочому просторі з покроковою перевіркою вільного простору. 
Попереднє сортування 3D-моделей виконується за збільшенням або зменшенням величини обраного критерію із таких характеристик: об’єм моделі, коефіцієнт використання робочого простору, мінімальний і максимальний габаритний розмір або їхня середньоарифметична величина.
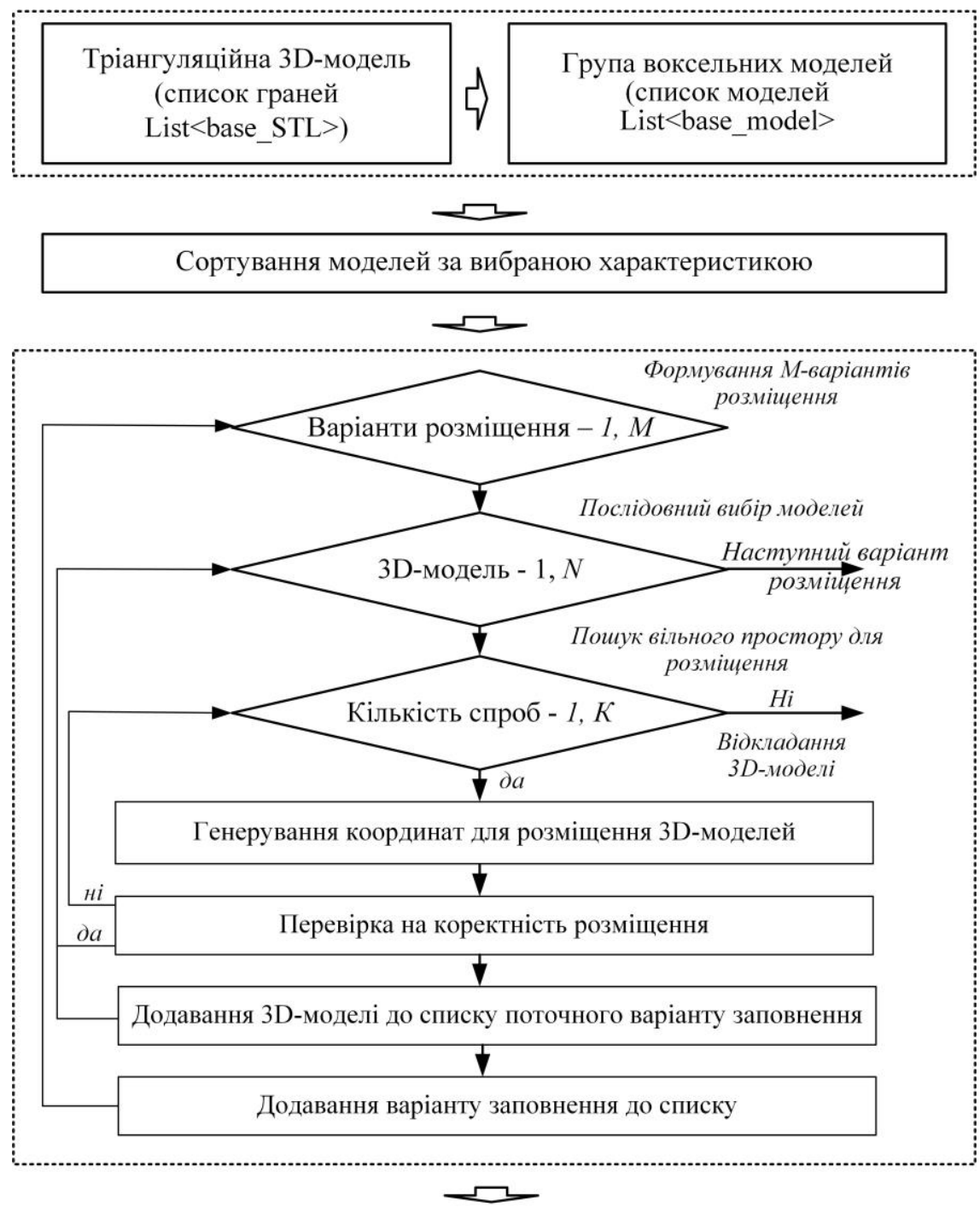

Визначення раціонального варіанту за вибраним критерієм

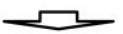

Аналіз розміщених 3D-моделей за кількістю заповнених і порожніх підпросторів та кількістю шарів побудови

Рис. 2. Схема алгоритму розміщення 3D-моделей виробів у робочому просторі з використанням методу Монте-Карло

Розміщення 3D-моделей виробів у робочому просторі виконується шляхом послідовного генерування координат з урахуванням розмірів робочого простору та габаритних розмірів виробу i перевірки на коректність розміщення. При цьому випадково генерується за законом рівномірного розподілу дві величини $x_{c i}$, $y_{c i}$ для координат по осях $X$, $Y$. Величина координати по осі $Z$ задається за умови мінімально допустимого розміщення у робочому просторі $Z_{\text {Amin }} 3$ урахуванням наявності раніше розміщених 3D-моделей. Оцінка мінімально допустимого розміщення поточної 3D-моделі виконується крок за кроком від координати $Z_{\min }$ (мінімальної величини по координатній осі $Z$ робочого простору) 3 кроком $\Delta_{\mathrm{z}}$, рівним за замовчуванням розміру вокселя $3 \mathrm{D}$-моделі.

Дослідження можливостей розробленого алгоритму розміщення 3D-моделей виробів виконано шляхом порівняльного аналізу за кількістю шарів $N_{L}$ та висоти побудови $H_{B}$ моделей промислових виробів (рис. 3). 
Апробація розробленого алгоритму (схема зазначена на рисунку 2) розміщення 3D-моделей виробів продемонструвала найменші витрати часу порівняно з іншими (наприклад, генетичними алгоритмами), що дозволяе істотно скоротити терміни на технологічну підготовку.

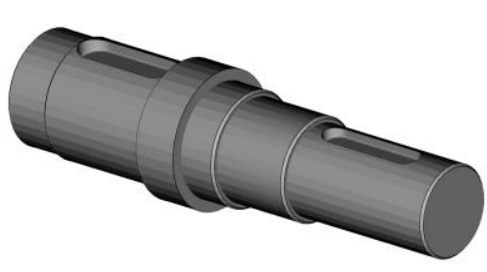

$a$

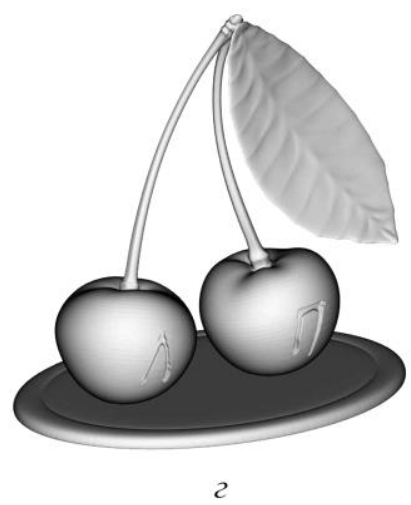

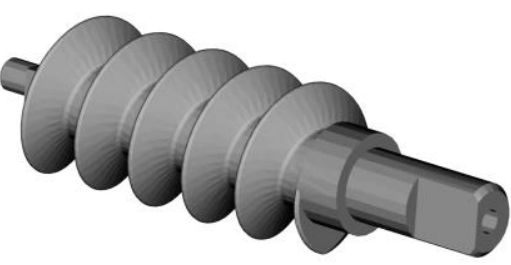

$\sigma$

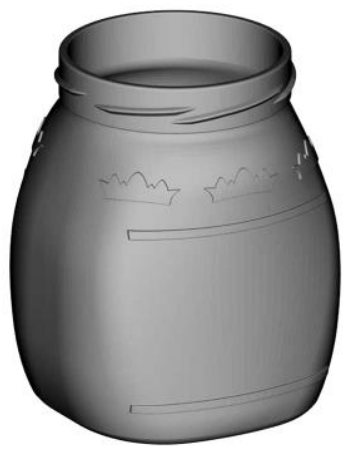

$\partial$
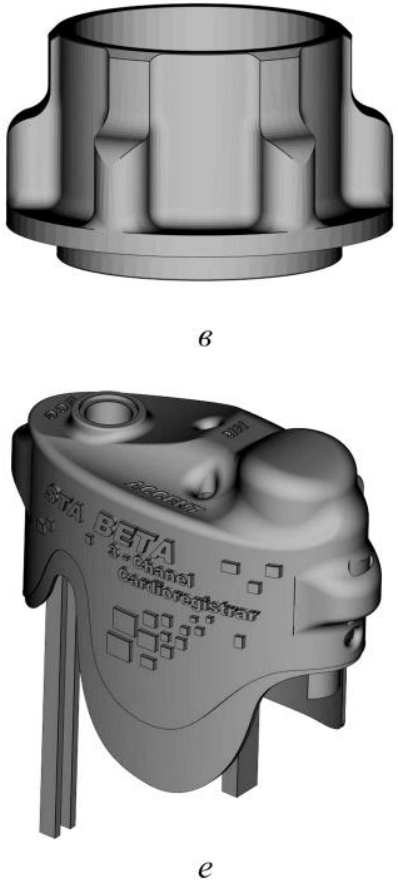

Рис. 3. Тестові 3D-моделі: а) вал; б) шнек; в) корпус; г) сувенір; д) ємність; е) кришка

Перевірка і дослідження працездатності розробленого алгоритму виконано на прикладі розміщення невеликої групи виробів. На початку використано групу з трьох 3D-моделей виробів (рис. $3, a-6$ ):

- вал (габаритні розміри 60х216х60 мм³, кількість граней $N_{t r}=147610$ шт., кількість вокселей $N_{\text {vox }}=47172$ шт. при розмірі вокселя 2 мм за всіма осями);

- $\quad$ корпус (210x210x125 мм³,$N_{t r}=3010$ шт., $N_{\text {vox }}=115029$ шт.);

- $\quad$ шнек (40x144x40 мм $^{3}, N_{t r}=10366$ шт., $N_{\text {vox }}=7978$ шт.).

Апробацію виконано для трьох варіантів попереднього сортування 3D-моделей. Статистичні характеристики (мінімальне, максимальне і середнє значення) досліджених ознак для отриманих 60 варіантів розміщення 3D-моделей у робочому просторі пошарової побудови наведено у таблиці 1. Розміри робочого простору задано на прикладі установки Vanguard Si2 SLS. Оцінку продуктивності виготовлення розглянуто за кількістю шарів побудови. Стратегію розсічення зі змінним кроком побудови виконано за таких характеристик: крок $h_{i} \in[0,1 ; 0,3]$ мм; гранично допустимій величині відхилення від правильної форми $\Delta_{S \max }=0,1$ мм.

Таблиияя 1

Статистичні характеристики кількості шарів побудови, одержаних при аналізі варіантів розміщення $3 D$-моделей

\begin{tabular}{|c|c|c|c|c|}
\hline \multirow{2}{*}{$\begin{array}{l}\text { Сортування } \\
\text { 3D-моделей }\end{array}$} & \multirow{2}{*}{$\begin{array}{c}\text { Статистичні } \\
\text { характеристики }\end{array}$} & \multicolumn{2}{|c|}{ Кількість шарів побудови при стратегії } & \multirow{2}{*}{$\begin{array}{c}\text { Висота } \\
\text { побудови } H_{B}, \\
\text { мм } \\
\end{array}$} \\
\hline & & постійний крок & змінний крок & \\
\hline Без сортування & $\begin{array}{l}\{\mathrm{x}\}_{\min }, \\
\{\mathrm{x}\}_{\max }, \\
\bar{x}\end{array}$ & $\begin{array}{l}1290 \\
1810 \\
1659 \\
\end{array}$ & $\begin{array}{c}863 \\
1105 \\
1036 \\
\end{array}$ & $\begin{array}{l}131,0 \\
183,0 \\
167,9 \\
\end{array}$ \\
\hline $\begin{array}{c}\text { Збільшення } \\
\text { об’єму }\end{array}$ & $\begin{array}{c}\{\mathrm{x}\}_{\min }, \\
\{\mathrm{x}\}_{\max }, \\
\bar{x}\end{array}$ & $\begin{array}{l}1251 \\
1800 \\
1614 \\
\end{array}$ & $\begin{array}{c}856 \\
1092 \\
1018 \\
\end{array}$ & $\begin{array}{l}127,0 \\
182,0 \\
163,4 \\
\end{array}$ \\
\hline $\begin{array}{c}\text { Зменшення } \\
\text { об’єму }\end{array}$ & $\begin{array}{l}\{\mathrm{x}\}_{\min }, \\
\{\mathrm{x}\}_{\max }, \\
\bar{x}\end{array}$ & $\begin{array}{l}1251 \\
1251 \\
1251 \\
\end{array}$ & $\begin{array}{l}807 \\
929 \\
861\end{array}$ & $\begin{array}{l}127,0 \\
127,0 \\
127,0 \\
\end{array}$ \\
\hline
\end{tabular}


За даними статистичного аналізу, наведеними в таблиці 1, виявлено істотний вплив виду попереднього сортування 3D-моделей на показники просторового розміщення та пошарового розсічення. Сортування 3D-моделей за зменшенням їхнього об'єму дає кращі результати, але при цьому спостерігалося деяке збільшення часу розрахунків.

Розміщення 3D-моделей за методом Монте-Карло не завжди дозволяло отримувати раціональні варіанти розміщення. При виконанні статистичного аналізу досліджених ознак явно невдалі варіанти розміщення «відкидалися», тобто не враховувалися. Таких варіантів виявлено менше 10 \% від загальної кількості.

3 метою поглиблення оцінки можливостей цього алгоритму розміщення додатково сформовано робочий простір АМ-установки для одержання 6 виробів. До трьох зазначених вище 3D-моделей додається (рис. 3, г-e):

- $\quad$ ємність $\left(102 \times 93,6 \times 125,5 \mathrm{mM}^{3}, N_{t r}=34424\right.$ шт., $N_{v o x}=68613$ шт.);

- $\quad$ кришка $\left(83,9 \times 101,3 \times 43,2 \mathrm{Mm}^{3}, N_{t r}=15352\right.$ шт., $N_{v o x}=33998$ шт.);

- $\quad$ сувенір (73х51,3х70,1 мм³ $N_{t r}=8090$ шт., $N_{\text {vox }}=19847$ шт.).

На прикладі розміщення 6 виробів розглянуто вплив кількості спроб визначення координат під час пошуку вільного простору $N_{\text {search }}$ на вихідні показники пошарової побудови. На рисунках 4-5 наведено одержані експериментальні дані щодо впливу числа $N_{\text {search }}$ на середньоарифметичну величину характеристик досліджених ознак 3 варіантів по кожному набору параметрів розміщення 3D-моделей у робочому просторі пошарової побудови. У всіх випадках попереднє сортування 3D-моделей виконувалося зі зменшенням їх об'єму.

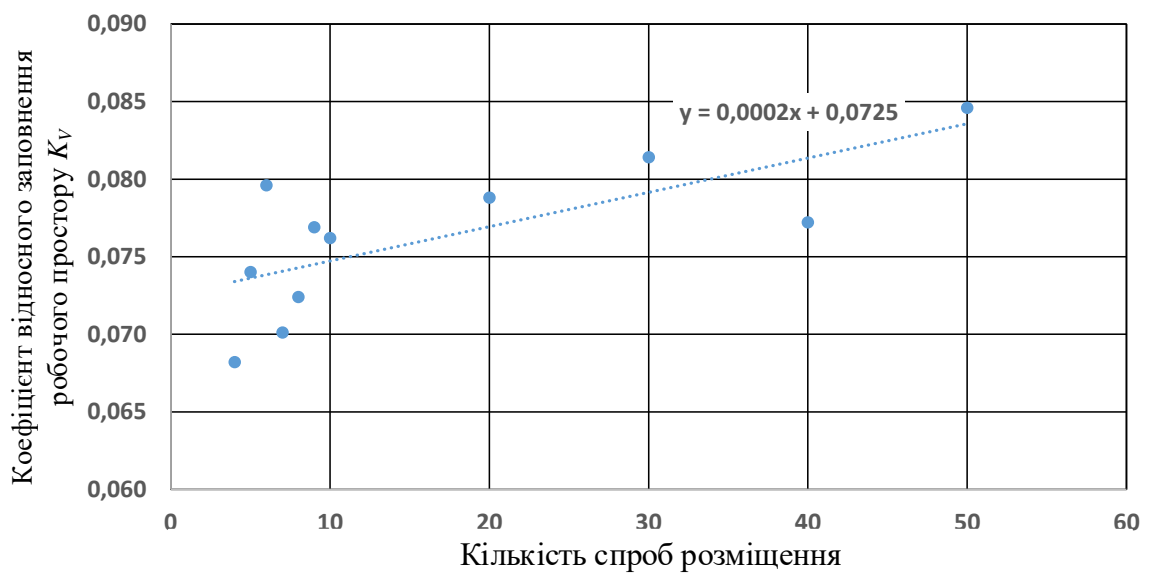

Рис. 4. Вплив кількості спроб розміщення 3D-моделей з використанням методу Монте-Карло на відносне заповнення робочого простору пошарової побудови

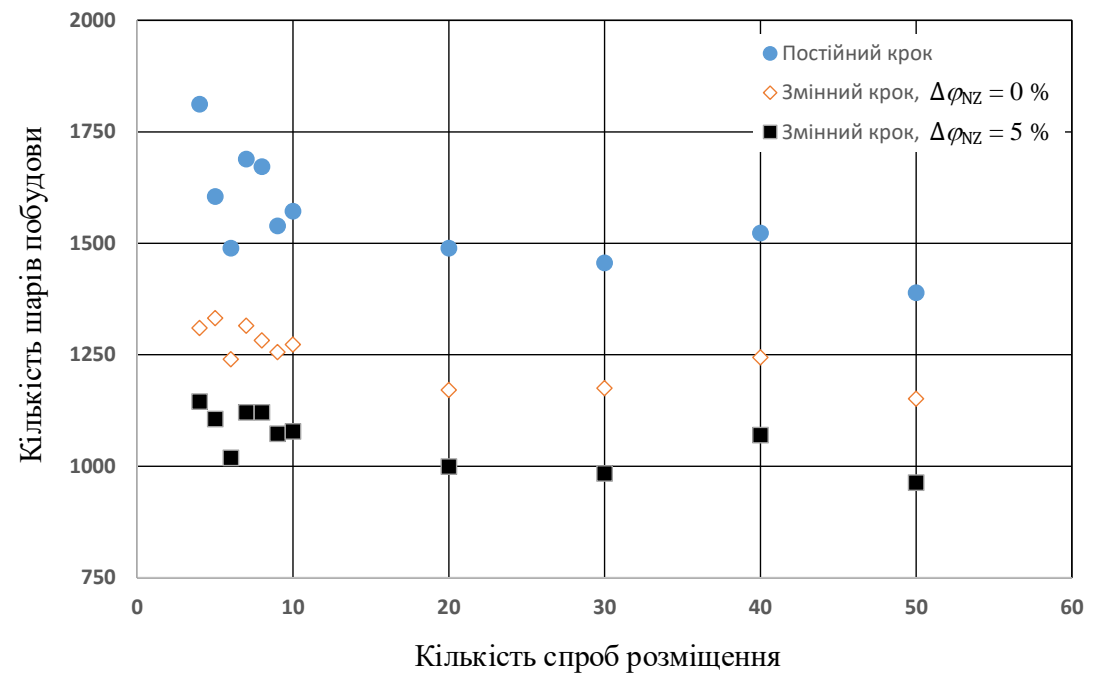

Рис. 5. Вплив кількості спроб розміщення 3D-моделей з використанням методу Монте-Карло на середньоарифметичну величину кількості шарів 
Одержані дані на рисунках 4 і 5 демонструють явне поліпшення досліджених показників зі збільшенням числа спроб розміщення (пошуку вільного простору) $N_{\text {search }} \in[4,5]$ для кожного кроку зміни координати розміщення по осі Z. Така тенденція має ймовірнісний характер опису цих залежностей. Визначення кількості шарів побудови групи виробів залежно від числа $N_{\text {search }}$ (рис. 5) дає можливість визначити практичні рекомендації щодо використання цього алгоритму, що мають сенс для розглянутих виробів. На основі отриманих результатів модельних досліджень виявлено раціональні параметри запропонованого алгоритму розміщення 3D-моделей виробів у робочому просторі за методом Монте-Карло.

Попереднє сортування необхідно виконувати за зменшенням об'єму (для 3D-моделей з простими за геометрією поверхнями) або габаритних розмірів (для складних 3D-моделей).

Крок завдання координат по осі $Z$ слід задавати залежно від вимог на терміни виконання технологічної підготовки матеріалізації виробів. Переважно крок переміщення 3D-моделі було задано рівним (не більшим) гранично допустимій величині мінімальної відстані між розміщеними 3D-моделями.

У разі виробів 3 простими за геометрією поверхнями і розподілу матеріалу в просторі, рекомендується формувати $3 \div 5$ варіантів розміщення. Стосовно до складних $-5 \div 10$. На кожному етапі розміщення поточної 3D-моделі виробу виконувалось $4 \div 7$ спроб визначення вільного простору. Для

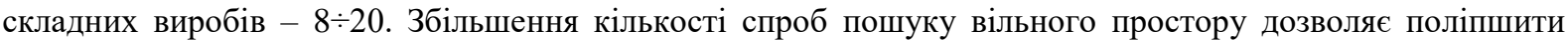
значення обраної цільової функції оптимізації.

Множина вокселей виробів $\epsilon$ за своєю суттю надмірною для задачі перевірки коректності розташування, тому в алгоритмі передбачено параметр вибору кожного $n$-го вокселя. Для простих $3 \mathrm{D}-$ моделей, залежно від співвідношення розміру вокселя до величини мінімальної відстані між розміщеними 3D-моделями, слід під час перевірки конфліктних вокселей вибирати кожний $10 \div 40$. Менша величина обирається при досить великих розмірах вокселя відносно величини мінімальної відстані між розміщеними 3D-моделями. Для складних моделей - 1\%9. Менша величина обирається у разі підвищених вимог до точності перевірки коректності розміщення. Наприклад, в разі розгляду невеликої кількості варіантів розміщення.

Висновки та перспективи подальших досліджень. Одержані результати досліджень дозволяють обгрунтовано рекомендувати використання методу Монте-Карло для ефективного виконання оптимізаційної задачі раціонального розташування 3D-моделей виробів у робочому просторі пошарової побудови установок адитивних технологій.

Розрахункові дані підтверджують достатню ефективність запропонованого алгоритму у випадку

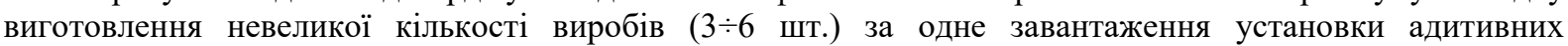
технологій. Витрачений час розрахунків із запропонованим алгоритмом $є$ суттєво меншим відносно ручного методу розміщення (у $3 \div 8$ разів на прикладі досліджених моделей), що дозволяє скоротити час на технологічну підготовку адитивного виробництва.

Результати роботи створюють методологічну основу для комплексного розв'язання задач технологічної підготовки адитивного виробництва. Подальші дослідження слід спрямувати на визначення умов ефективного виконання задачі раціонального розміщення виробів у робочому просторі пошарової побудови під час використання генетичного алгоритму.

\section{Список використаної літератури:}

1. Zhang $Y$. AM feature and knowledge based process planning for additive manufacturing in multiple parts production context / Y.Zhang, A.Bernard // In Proceedings of 25th Annual International Solid Freeform Fabrication Symposium. - 2014. - P. 1259-1276 [Electronic recourse]. - Access mode : http://sffsymposium.engr.utexas.edu/sites/default/files/2014-099-Zhang.pdf.

2. Wohlers Report 2016. 3D Printing and additive manufacturing state of the industry. Annual worldwide progress report. - 2016 [Electronic recourse]. - Access mode : https://wohlersassociates.com.

3. Миротин Л.Б. Логистика, технология, проектирование складов, транспортных узлов и терминалов / Л.Б. Миротин, А.В. Бульба, В.А. Демин. - М. : Феникс, 2009. - 408 с.

4. Псиола В.B. О приближенном решении 3-х мерной задачи об упаковке на основе эвристик / B.B. Псиола // Интеллектуальные системы. - 2011. - Вып. 1. - С. 83-100.

5. Верхотуров М.A. Задача нерегулярного размещения геометрических объектов: современное состояние методов решения / М.A. Верхотуров // Ресурсосберегающие технологии. - СПб : ЦНИИТС, 2001. - С. 33-56.

6. Верхотуров М.A. Об одном решении задачи плотной упаковки выпуклых многогранников на основе годографа функции плотного размещения / М.A. Верхотуров, Г.Н. Верхотурова, Р.Р. Ягудин // Информационные системы и технологии. - Орел, 2012. - № 4. - С. 31-39.

7. Верхотурова Г.Н. Построение годографа функции плотного размещения двух многогранников / Г.Н. Верхотурова, Р.Р. Ягудин // Принятие решений в условиях неопределенности. - Уфа : УГАТУ, 2010. Вып. 7. - С. 150-157.

8. Stoyan Y. Packing of convex polytopes into a parallelepiped / Y.Stoyan, N.Gil, G.Scheithauer // Preprint MATHNM-06-2004. - Dresden, 2004. - P. 32.

9. Bezdek K. Classical topics in discrete geometry / K.Bezdek. - New York : Springer, 2010 [Electronic recourse]. Access mode : 10.1007/978-1-4419-0600-7. 
10. Автоматизированное проектирование радиоэлектронных средств : учебное пособие для вузов / О.В. Алексеев и др.; под ред. О.В. Алексеева. - М. : Высш. шк., 2000. 479 с.

11. Dykhoff H. A typology of cutting and packing problems / H.Dykhoff // Evropean Journal of Operational research. 1990. - Vol. 44. - P. 145-159.

12. Pandey P.M. Slicing procedures in layered manufacturing: a review / P.M. Pandey, N.V. Reddy, S.G. Dhande // Rapid Prototyping Journal. - 2003. - Vol. 9, Issue 5. - P. 274-288 [Electronic recourse]. - Access mode : https://doi.org/10.1108/13552540310502185.

13. Абдурайимов Л.Н. Адаптивное разделение на слои исходной $3 \mathrm{D}$ модели изделия в технологиях быстрого прототипирования и изготовления / Л.Н. Абдурайимов // Ученые записки Крымского инженернопедагогического университета. Серия : Технические науки. - Симферополь : НИЦ КИПУ, 2009. Вып. 18. - C. 15-20.

14. Byun H.S. Determination of optimal build direction in rapid prototyping with variable slicing / H.S. Byun, K.H. Lee // Int J Adv Manuf Technol. - 2006. - Issue 28. - P. 307-313. [Electronic recourse]. - Access mode : $10.1007 / \mathrm{s} 00170-004-2355-5$

\section{References:}

1. Zhang, Y. and Bernard, A. (2014), «AM feature and knowledge based process planning for additive manufacturing in multiple parts production context», In Proceedings of 25th Annual International Solid Freeform Fabrication Symposium, pp. 1259-1276, [Online], available at: http://sffsymposium.engr.utexas.edu/sites/default/files/2014099-Zhang.pdf

2. Wohlers Report 2016, (2016), «3D Printing and additive manufacturing state of the industry. Annual worldwide progress report», [Online], available at: https://wohlersassociates.com

3. Mirotin, L.B., Bul'ba, A.V. and Demin, V.A. (2009), Logistika, tehnologija, proektirovanie skladov, transportnyh uzlov i terminalov, Feniks, M., 408 p.

4. Psiola, V.V. (2011), «O priblizhennom reshenii 3-h mernoj zadachi ob upakovke na osnove jevristik», Intellektual'nye sistemy, Issue 1, pp. 83-100.

5. Verhoturov, M.A. (2001), «Zadacha nereguljarnogo razmeshhenija geometricheskih ob'ektov: sovremennoe sostojanie metodov reshenija», Resursosberegajushhie tehnologii, CNIITS, SPb, pp. 33-56.

6. Verhoturov, M.A., Verhoturova, G.N. and Jagudin, R.R. (2012), «Ob odnom reshenii zadachi plotnoj upakovki vypuklyh mnogogrannikov na osnove godografa funkcii plotnogo razmeshhenija», Informacionnye sistemy $i$ tehnologii, Orel, No. 4, pp. 31-39.

7. Verhoturova, G.N. (2010), «Postroenie godografa funkcii plotnogo razmeshhenija dvuh mnogogrannikov», Prinjatie reshenij v uslovijah neopredelennosti, UGATU, Ufa, Vol. 7, pp. 150-157.

8. Stoya, Y., Gil, N. and Scheithauer, G. (2004), Packing of convex polytopes into a parallelepiped, Preprint MATHNM-06-2004, Dresden, 32 p.

9. Bezdek, K. (2010), Classical topics in discrete geometry, Springer, New York, [Online], available at: 10.1007/978$1-4419-0600-7$

10. Alekseev, O.V. (2000), Avtomatizirovannoe proektirovanie radiojelektronnyh sredstv, uchebnoe posobie dlja vuzov, in Alekseev, O.V. (ed.), Vysshaja shkola, M., 479 p.

11. Dykhoff, H. (1990), «A typology of cutting and packing problems», Evropean Journal of Operational research, Vol. 44, pp. 145-159.

12. Pandey, P.M., Reddy, N.V. and Dhande, S.G. (2003), «Slicing procedures in layered manufacturing: a review», Rapid Prototyping Journal, Vol. 9, Issue 5, pp. 274-288, [Online], available at: 10.1108/13552540310502185

13. Abdurayimov, L.N. (2009), "Adaptivnoe razdelenie na sloi iskhodnoy 3D modeli izdeliya v tekhnologiyakh bystrogo prototipirovaniya i izgotovleniya», Uchenye zapiski Krymskogo inzhenerno-pedagogicheskogo universiteta, Seryja Tekhnicheskie nauki, NITs KIPU, Simferopol', Vol. 18, pp. 15-20.

14. Byun, H.S. and Lee, K.H. (2006), «Determination of optimal build direction in rapid prototyping with variable slicing», Int J Adv Manuf Technol, Issue 28, pp. 307-313, [Online], available at: 10.1007/s00170-004-2355-5

Гаращенко Ярослав Миколайович - кандидат технічних наук, доцент кафедри інтегрованих технологій машинобудування Національного технічного університету «Харківський політехнічний інститут».

Наукові інтереси:

- адитивні технології;

- зворотній інжиніринг;

- моделювання алмазно-абразивних інструментів.

E-mail: yaroslav.garashchenko@gmail.com.

Зубкова Ніна Вікторівна - кандидат технічних наук, доцент кафедри інтегрованих технологій машинобудування Національного технічного університету «Харківський політехнічний інститут».

Наукові інтереси:

- адитивні технології;

- зворотній інжиніринг.

E-mail: zubkova.nina@gmail.com. 